\title{
Corporate Governance and Audit Fees Evidence from Bangladeshi Listed Banks and NBFIs
}

\author{
Tusher Ghosh ${ }^{1, *}$ \\ ${ }^{1}$ Institute for Financial and Accounting Studies, Xiamen University, Fujian, P.R. of China \\ *Correspondence: Room 206, Nanguang 4, South Siming Road, Xiamen University, Xiamen, \\ Fujian, P.R. of China. E-mail: tusherghosh@stu.xmu.edu.cn
}

Received: October 19, 2019 Accepted: November 18, 2019 Published: November 25, 2019

doi: 10.5296/jcgr.v3i1.15638 URL: https://doi.org/10.5296/jcgr.v3i1.15638

\begin{abstract}
The study examines influence of corporate governance mechanisms on audit fees in listed Bangladeshi banks and non-bank financial institutions (NBFIs) with Dhaka Stock Exchange. Data have been collected from published annual reports of the 46 firms covering the period of 2013-2017. Among them 30 firms are banking companies the remaining firms belong to NBFIs. Using fixed-effect model, the study finds that board independence, female member representation in board, board diligence as well as audit committee diligence have positive influence on audit fees. As opposed to previous literature, the study reports that in the context of Bangladeshi banks and NBFIs board size, audit committee size, audit committee independence are negatively associated with audit fees.
\end{abstract}

Keywords: corporate governance, audit fees, Bangladeshi, banks, NBFIs 


\section{Introduction}

Corporate governance is the system by which companies are directed and controlled to facilitate effective, entrepreneurial and prudent management that can deliver the long-term success of the company (FRC, 2012). The numerous scandals at the global level, especially the high-profile cases like Enron, Parmlat, Tyco, AIG, WorldCom, Lehman Brothers, Waste Management, Olympus, etc., eroded the credibility of financial reporting (Paltrow, 2002). As a result, the area of corporate governance has turned into a center of attention to the researchers around the globe. For the purpose of ensuring good corporate governance practices many countries officially implemented different laws and procedures such as Sarbanes-Oxley Act (2002) in USA, Australian Treasury Act (2002) and Higgs Report (2003) in the UK, SEBI's corporate governance guidelines in India. In Bangladesh, BSEC has published official 'Corporate Governance Code' in 2018 in order to enhance corporate governance in the interest of investors and the capital market and has made the following of Code mandatory for every listed companies with any stock exchanges of Bangladesh.

For financial and economic entities corporate governance is considered as an important topic. Because in developing-economy financial systems, capital market is comparatively weak as a result the banks are the major source of finance for most of the firms. It allows banks to hold a dominant position and considered as extremely important engines of economic growth (King \& Levine, 1993a, b; Levine, 1997; Levine, 2004).

In Bangladesh perspective, numerous research activities have been conducted on various issues of corporate governance mostly like corporate governance practices in Bangladesh (Hossain \& Rahman, 2013; Mahmud \& Ara, 2015; Shamsuddoha, 2003), history of it (Biswas, 2015), problems and prospects in Bangladesh (Huq \& Bhuiyan, 2012; Wise et al., 2014) impact of it in various factors like performance (Alam \& Akhter 2017; Ahmed et al., 2008), NPL (Saha \& Ghosh, 2019) and CSR (Khan, 2010) etc. Similarly, the research activities regarding audit fee in Bangladesh have mostly centered on finding the determinants of it (Karim \& Moizer 1996; Karim and Hasan, 2012; Safiuddin and Mohsin, 2016).

However, very few studies have scrutinized the possible association between audit fee and the factors of corporate governance in Bangladesh. Haque et al. (2019) examined 40 listed insurance companies with Dhaka Stock Exchange to observe the relationship of corporate governance with audit fees. The study was conducted by using a composite score of four dichotomous corporate governance variable and found a positive relationship between CG variables and audit fees.

Although the research evidence from different countries shows mixed results regarding this issue. Bortolon et al. (2013) examined the sample of 131 companies in Brazil and concluded that a negative relationship exists between corporate governance and the cost of the independent audit. Similarly, Wu (2012) used data of listed companies with Shanghai Stock Exchange and found a significant negative relationship between corporate governance and audit fees.

On the other hand, Harris (2007) sampled 100 publicly traded corporations drawn from the 
2005 Fortune 500 list and concluded that a significant positive relationship between expertise (audit committee financial experts and the average number of outside directorships held by board members) and audit fees. In the same vein, Urhoghide \& Izedonmi (2015) examined Nigerian Stock Exchange data from 2007-2012 and concluded board diligence, board expertise, board size, board independence, and audit committee independence, all have a positive and significant impact on audit fee. Hassan et al. (2014) used 37 publicly traded firms listed at Karachi Stock Exchange (KSE) and found corporate governance, firm size and leverage have a positive relationship with audit fee. Likewise, Farooq et al. (2018) examined five years data of KSE-100 and found effective board quality has positive association but audit committee effectiveness reduces the external audit fee.

Husnin et al. (2013) scrutinized internal corporate governance mechanisms with audit fee in Malaysia and found that the Malaysian Code of Corporate Governance influenced the determinants of audit fee. Hamza (2018) studied 26 Jordanian insurance companies and found significant impact of corporate governance principles on the auditor's independence and audit fees.

In this situation, this paper attempts to examine factors of corporate governance and scrutinize the possible association between corporate governance and audit fees in the context of Bangladeshi listed banks and non-bank financial institutions (NBFIs) with Dhaka Stock Exchange (DSE). The aim of this paper is to find out the association between the studied variables and compare it with the international evidence.

\section{Literature Review and Statement of Hypothesis}

Good corporate governance is said to be the most valuable practice for the success of any business. Corporate governance first came into vogue in the 1970s in the United States. Within 25 years corporate governance had become the subject of debate worldwide by academics, regulators, executives and investors (Cheffins, 2013). However, in emerging economies studies on corporate governance have not gained the same momentum as in the developed markets (Shleifer \& Vishny, 1997; Gibson, 2003; Denis \& McConnel, 2003).

\subsection{Board Size}

Beiner et al. (2004) suggested the size of the board of directors is an independent corporate governance mechanism. The literature on the effectiveness of board size on its monitoring efficiency is mixed (Farooq et al., 2018) some argue smaller board size is more effective (Simpson and Gleason, 1999; Belkhir, 2006; Altunbas et al., 2001) while others argue the opposite scenario (Lipton \& Lorsch, 1992; Jensen, 1993). However, in relation to audit fee studies suggest that there is a positive association between external auditor fees with board size (Kikhia, 2014; Karim et al., 2015; Jizi \& Nehme, 2018). Larger and classified boards seek better monitoring from external auditors which leading to increased audit fees (Jizi \& Nehme, 2018). Thus, the hypothesis to be empirically tested is as follows:

$\mathbf{H}_{1}$ : There is a positive relationship between the board size and audit fees in Bangladesh 


\subsection{Board Independence}

For listed companies the appointment of independent directors is essential in order to ensure good corporate governance. One of the main reasons behind appointing independent directors is to ensure objectivity so that they can evaluate the performance and wellbeing of a company without having any conflict of interest or undue influence (Sattar, 2018). Even though empirical findings on the board independence and perform is mixed in the literature (Saha \& Ghosh, 2019), the previous studies suggest a positive relation exit between board independence and audit fees (Jizi \& Nehme, 2018; Bozec \& Dia, 2017; Kikhia, 2014; Carcello et al., 2002). Carcello and Neal (2000) argued that the existence of independent directors leads to greater concern about audit quality in comparison to the presence of executive directors. As a result, companies with more independent directors and effective audit committees assign higher-quality auditors (Abbott \& Parker, 2000). These findings support the notion that, independent board members try to avoid any mishaps before they occur by trying to ensure high quality external audit because their reputation is at stake and which in turn increases audit fees paid for external auditing. So in alignment with above arguments the following hypothesis can be drawn:

$\mathbf{H}_{2}$ : There is a positive relationship exists between the board independence and audit fees in Bangladesh

\subsection{Board Diligence}

An important facet of corporate governance that has gained prominence of late has been the board of directors of the firm (Hermalin, 2005). Vafeas (1999) has argued, board meeting frequency is an important dimension of board operations and unless the board is diligent the independence or size of the board cannot in themselves lead to effectual in the monitoring role. Regular meeting attendance is considered a hallmark of the conscientious director (Sonnenfeld, 2002). Because regular meeting attendance is it likely to inform the members about the relevant performance of the company and direct the appropriate action to address the current issue. Carcello et al., (2002) argued a board that demonstrates greater diligence by the number of board meetings may seek an enhanced level of oversight of the financial reporting process. Harris (2007) noted boards that meet more often can interact with the audit committee, and thus may influence audit activity and coverage during various stages of the audit. As a result, a diligent board will demand proper scrutiny of the reporting process by high quality auditors and thus it will it will ultimately lead to an increase of audit fees. Form the above discussion the following hypothesis can be drawn:

$\mathbf{H}_{3}$ : There is a positive relationship exists between the board diligence and audit fees in Bangladesh

\subsection{Female Members Representation in Board}

Recent studies has confirmed that gender diversity may have important implications for corporate governance. For example, Carter et al., (2003) noted board diversity is associated with an improved financial value. Erhardt et al., (2003) suggested board diversity is positively associated with financial indicators of firm performance. Adams \& Ferreira (2009) 
suggested that gender-diverse boards allocate more effort to monitor. The literature also suggests that women are more sensitive to ethical issues than men in decision making. Say, Bernardi \& Arnold, (1997) concluded female managers are at a significantly higher average level of moral development than male managers. However, literature in terms of board's gender diversity and auditor selection exhibit mixed results. Lai et al., (2017) examined how female audit committee members affect audit quality on the basis of data from U.S. firms and concluded that firms with gender-diverse boards pay higher audit fees and are more likely to choose specialist auditors compared to their peers. Huang et al., (2014) also studied U.S. firms and found an association between firms with female CEOs and higher audit fees. Ittonen \& Peni (2012) found the same result using a sample of public firms from the NASDAQ OMX exchanges in three Nordic countries. Hardies et al., (2015) studied Belgian firms and concluded higher audit fees for female audit engagement partners. Likewise, Khlif $\&$ Achek (2017) studies dealing with gender issues in accounting literature over the period of 1994-2016 and found findings shows that female representation on the board, audit committee, CFO or CEO leads to higher audit fees along with more conservative reporting, higher level of social and environmental disclosure, less tax aggressiveness. In line with the above literature, it is argued that as female members are more cautious about the firm's performance and ethical issues, they tend to ensure higher audit quality given by specialist external auditors and thus audit fees increase.

$\mathbf{H}_{4}$ : There is a positive relationship exists between the female member representation in the board and audit fees in Bangladesh

\subsection{Audit Committee Size}

As stated by CFA(note 1) Institute, the primary purpose of a company's audit committee is to provide oversight of the financial reporting process, the audit process, the company's system of internal controls and compliance with laws and regulations. Crişan \& Fülöp (2014) stated that the role of the audit committee is crucial and plays a major role in corporate governance regarding the organization's direction, control, and accountability (Al-Baidhani, 2016). The size of the audit committee is considered a measure for audit quality. The size itself provides an indicator of an effectual discharge of committee duties (Chartered Institute of Management Accountants, 2000). Stewart \& Kent (2006) found the relation of higher audit fees with the existence of an audit committee, committee meetings and increased use of internal audit. Ali et al., (2018), also found that audit committee effectiveness has a positive significant impact on both audit fees and non-audit fees. In the same vein, Azmi et al., (2013) after analyzing Malaysian listed companies opined audit committee size is significant and has a positive association with audit fees. The presence of an audit committee should ensure that audit hours are at a level that does not compromise the quality of the audit, which may lead to an increase in audit fees (Collier \& Gregory, 1996). As the results of previous literatures supports positive association, therefore following hypothesis has been tested:

H5: There is a positive relationship exists between the audit committee size and audit fees in Bangladesh 


\subsection{Audit Committee Independence}

In recent years the interest in firm's internal audit committee as a part of overall corporate governance has increased dramatically and emphasis is being given on member independence, experience, and knowledge (Rahim et al., 2015; DeZoort \& Salterio, 2001). Smith Committee (2003) had recommended four criteria of a good audit committee of which the first criteria recommended that all members of the committee should be independent non-executive director. Similarly, the Para 5.2 (b) of Bangladesh Corporate Governance Code (BCGC) stated that the board shall appoint members of the audit committee who shall be non-executive directors of the company excepting Chairperson of the board and shall include at least one independent director. Audit committees with independent directors can be regarded as better equipped to maintain the integrity of company financial statements (Klien, 2002; Vera-Munoz, 2005) thus more cautious regarding the occurrence of fraud in financial statements (Beasley et al., 2000). Abbott et al., (2003) and Carcello et al., (2002) found that the more independent audit committees demand a higher quality audit service thus will result in higher audit fees. In line with the above discussion the following hypothesis has been developed:

H5: There is a positive relationship exists between the audit committee independence and audit fees in Bangladesh

\subsection{Audit Committee Diligence}

Prior studies have identified diligence as one of the most important measures in quantifying the effectiveness of an audit committee (Kalbers \& Fogarty, 1993; Willekens et al., 2004; Méndez \& García, 2007; Sharma et al., 2009; Greco, 2011). However, the number of audit committee meetings is considered as the most quantitative signal about the diligence of audit committees (DeZoort et al., 2002; Raghunandan \& Rama, 2007; Méndez \& García, 2007; Sharma et al., 2009; Greco, 2011, Yin et al., 2012). A diligent internal audit committee can ensure strong internal control system, reliability of financial reporting, improve transparency and thus contribute to the overall enhancement of the firm's value. By performing the activities diligent audit committees can reduce the risks associated with financial fraud (Beasley, 1996) and improve the information environment (Fakhari \& Pitenoei, 2017) which leads to lesser external audit effort and thus result in lower audit fees. However, it is interesting to see that a bunch of studies has developed a hypothesis on that argument, but none of them managed to prove a negative association between audit committee diligence and audit fees (Farooq et. al., 2018; Jizi \& Nehme, 2018; Yatim et al., 2006; Stewart \& Kent 2006; Abbott et. al., 2003). Only Azmi et al., (2013) found a negative relation by examining 120 observations of year 2008 of Bursa Malaysia listed companies. Surprisingly Yatim et al., (2006) used the same listed companies, but a larger observation of 736 firms of the year ending 2003 and found straight opposite result. In this problematic situation it is really confusing to state a hypothesis. But due to the recent study results the following hypothesis has been drawn: $\mathbf{H}_{6}$ : There is a positive relationship exists between the audit committee diligence and audit fees in Bangladesh 


\subsection{Audit Fee and its Determinants}

Simunic (1984) defined the audit fee as a cost associated with the audit services which are demanded by client. Audit fee is the economic remuneration for auditors who provide audit services (Liu, 2017). The preponderance of research activities has been conducted to unveil determinants of audit fee over the years. Studies based on developed economies include but not limited to Rubin (1988); Chan et al., (1993); Brinn et al. (1994); Moizer (1997); Langendijk (1997); Taylor \& Simon (1999); Mellett et al., (2007); Gonthier-Besacier \& Schatt (2007); Bedard \& Johnstone (2010). Similarly, amongst the studies of emerging economies Karim \& Moizer (1996); Naser \& Nuseibeh (2008); Karim \& Hasan (2012); Hassan \& Naser (2013); Kikhia (2015); Haq \& Leghari (2015) studied the determinants of audit fees in developing countries around the world.

Urhoghide \& Izedonmi (2015) opined it will be misleading to assume the findings regarding audit fee determinants in the developed countries can exactly be the same as in the developing economies. However, this study the purpose of which is to find the impact of corporate governance variables on audit fee include a couple of variables common in the prior literature and test them as control variables.

\section{Methodology of the Study}

\subsection{Data Source}

The prime purpose of this study is to investigate the association between audit fee and corporate governance variables with the presence of control variables that reported significant association with the dependent variable in prior studies. To test the hypothesis, data has been gathered from following listed firms with Dhaka Stock Exchange (DSE).

Table 1. Sample Description

\begin{tabular}{lcccc}
\hline Firm Type & Population & Sample & Percentage & Period (Years) \\
\hline Bank & 30 & 30 & $100 \%$ & $2017-2013$ \\
Non-bank financial institute (NBFI) & 23 & $16($ note 2$)$ & $69.5 \%$ & \\
Total sample size $=$ & 53 & 46 & $86.79 \%$ & $2017-2013$ \\
\hline
\end{tabular}

The published annual reports of each observed organization have been collected from the respective website of it. For analysis purpose the study used EViews 9 along with Gretl. 


\subsection{Measurement of Variables}

Table 2. Estimation of Corporate Governance Variables and Audit Fees

\begin{tabular}{|c|c|c|}
\hline Variable Name & Symbol & Operational Definition \\
\hline Audit Fees (Dependent Variable) & LnAUDFEE & Natural log of audit fees \\
\hline Board Size & BODSIZE & Number of members in board \\
\hline Board Independence & BODIND & $\begin{array}{l}\text { Proportion of independent director (ID) to total } \\
\text { number of directors }\end{array}$ \\
\hline Board Diligence & BODDILI & $\begin{array}{l}\text { Total number board meetings held in the } \\
\text { financial year }\end{array}$ \\
\hline $\begin{array}{l}\text { Female Members Representation in } \\
\text { Board }\end{array}$ & BODFEM & Proportion of female members in board \\
\hline Audit Committee Size & ACSIZE & Number of members in $\mathrm{AC}$ \\
\hline Audit Committee Independence & ACIND & Proportion of independent director in $\mathrm{AC}$ \\
\hline Audit Committee Diligence & ACDILI & $\begin{array}{l}\text { Total number AC meetings held in the financial } \\
\text { year }\end{array}$ \\
\hline
\end{tabular}

Table 3. Estimation of Control Variables

\begin{tabular}{|c|c|c|c|c|}
\hline $\begin{array}{l}\text { Variable } \\
\text { Name }\end{array}$ & Symbol & Operational Definition & Source & Exp. Sign \\
\hline Firm Size & LnFSIZE & The natural log of total asset & $\begin{array}{l}\text { Chan et al. (1993); Karim } \\
\text { \& Moizer (1996); Naser \& } \\
\text { Nuseibeh (2008) }\end{array}$ & + \\
\hline Profitability & PROFIT & $\begin{array}{l}\text { Ratio of profit after tax (PAT) } \\
\text { divided by total assets }\end{array}$ & $\begin{array}{l}\text { Haq \& Leghari (2015); } \\
\text { Jizi \& Nehme (2018) }\end{array}$ & - \\
\hline Complexity & ComX & Number of subsidiaries the firm has & Langendijk (1997) & + \\
\hline Loss & LOSS & $\begin{array}{l}\text { Dummy variable; assigned } 1 \text { (one) } \\
\text { if firm experienced a loss during } \\
\text { the year. }\end{array}$ & Haq \& Leghari (2015) & + \\
\hline Big 4 & BIG4 & $\begin{array}{l}\text { Dummy variable; assign } 1 \text { if firm's } \\
\text { external audit has Big } 4 \text { affiliation }\end{array}$ & $\begin{array}{l}\text { Karim \& Moizer (1996); } \\
\text { Haq \& Leghari (2015) }\end{array}$ & + \\
\hline
\end{tabular}

Table 4. Big 4 Affiliated Firms in Bangladesh

\begin{tabular}{llccc}
\hline \begin{tabular}{c} 
Global Name of \\
\multicolumn{1}{c}{ Big 4 }
\end{tabular} & Local Names & $\begin{array}{c}\text { Year of Local Firm's } \\
\text { Establishment }\end{array}$ & $\begin{array}{c}\text { Affiliation Status } \\
\text { with Big 4 }\end{array}$ & $\begin{array}{c}\text { Length of } \\
\text { Affiliation (since) }\end{array}$ \\
\hline KPMG & Rahman Rahman Huq & 1962 & Member & 2006 \\
PwC & A. Qasem \& Company & 1953 & Correspondent & 1978 \\
Deloitte(note 3) & Hoda Vasi Chowdhury & 1972 & Correspondent & 1998 \\
Ernst \& Young & S.F. Ahmed \& Co. & 1958 & Correspondent & 1975 \\
\hline
\end{tabular}

Source: Belal et al., (2017) 


\subsection{Model Specification}

The study uses the following regression models to test the hypothesis

i) Model 1:

LnAUDFEE $=\mathrm{C}+\beta_{1} \mathrm{LnSIZE}_{t}+\beta_{2} \mathrm{PROFIT}_{t}+\beta_{3} \mathrm{ComX}_{t}+\beta_{4} \mathrm{LOSS}_{t}+\beta_{5} \mathrm{BIG}_{t}+\varepsilon$

ii) Model 2:

LnAUDFEE $=\mathrm{C}+\beta_{1} \mathrm{BODSIZE}_{t}+\beta_{2} \mathrm{BODIND}_{t}+\beta_{3} \mathrm{BODDILI}_{t}+\beta_{4} \mathrm{BODFEM}_{t}+\beta_{5} \mathrm{ACSIZE}_{t}$ $+\beta_{6} \mathrm{ACIND}_{t}+\beta_{7} \mathrm{ACDILI}_{t}+\beta_{8} \mathrm{LnSIZE}_{t}+\beta_{9} \mathrm{PROFIT}_{t}+\beta_{10} \mathrm{ComX}_{t}+\beta_{11} \mathrm{LOSS}_{t}+\beta_{12} \mathrm{BIG}_{t}+\varepsilon$

Here,

$C=$ intercept;

$\beta_{1} \ldots . . \beta_{n}=$ regression coefficient;

$t=$ period indicator; and

$\varepsilon=$ error term;

Model 1 estimates the association between dependent variable and control variables only however in Model 2 all the experiment variables have been added along with Model 1 variables.

As it is a panel data study, Breusch-Pagan test have been applied to finding out if there is any possibility of having heteroskedasticity in the model. The results $(p=0.000)$ confirmed the rejection of the null and infer the presence of heteroskedasticity. To choose between random effect (REM) and fixed effect (FEM) model the Hausman test is conducted. The results $(p=0.01)$ confirmed that the difference in coefficients is systematic and consequently, the FEM should be used. Both models have been examined using fixed-effect panel linear regression more specific, one-way fixed time effect model with robust standard errors.

\section{Results and Discussion}

\subsection{Descriptive Statistics}

Table 5 reveals the descriptive statistics of all the variables used in the study. Starting from audit fees (AUDFESS) it has been observed that the average amount of audit fee in Bangladeshi banks and NBFIs is BDT 1.095 million. The observed minimum amount is BDT 75,000 while the highest amount for the period is BDT 6.811 million. Board size (BODSIZE) ranges from 22 members to 6 while the average is 13 members approximately. Board independence (BODIND), on the other hand, scores 0.193 which means on average $19.3 \%$ of the directors of board are independent. While the highest percentage of independence in board is 57.1 while the lowest is zero, meaning non-existence of independent director on board. The study finds, the average number of board meetings (BODDILI) is 17 (approx.) but the number of board meetings can reach up to 51 per year. The proportion of female members 
on board (BODFEM) has a mean value of 0.111 meaning that on average $11.1 \%$ directors are female. While the proportion can be reached up to $37.5 \%$, some companies have no female directors at all.

Table 5. Descriptive Statistics $(\mathrm{N}=230)$

\begin{tabular}{lcccc}
\hline Variable & Mean & $\begin{array}{c}\text { Standard } \\
\text { Deviation }\end{array}$ & Minimum & Maximum \\
\hline AUDFEES (Million) & 1.095 & 1.091 & 0.075 & 6.811 \\
BODSIZE & 13.19 & 3.536 & 6.00 & 22.0 \\
BODIND & 0.193 & 0.080 & 0.00 & 0.571 \\
BODDILI & 16.82 & 8.017 & 4.00 & 51.0 \\
BODFEM & 0.111 & 0.098 & 0.00 & 0.375 \\
ACSIZE & 4.57 & 0.821 & 3.00 & 7.00 \\
ACIND & 0.389 & 0.165 & 0.000 & 1.00 \\
ACDILI & 8.17 & 4.787 & 4.00 & 26.0 \\
FSIZE (Million) & $154,607.28$ & $137,356.17$ & 4223.00 & $899,599.00$ \\
PROFIT & 0.011 & 0.007 & 0.00 & 0.036 \\
ComX & 2.00 & 1.664 & 0.00 & 7.00 \\
LOSS & 0.05 & 0.214 & 0.00 & 1.00 \\
BIG4 & 0.35 & 0.479 & 0.00 & 1.00 \\
\hline
\end{tabular}

However, the average size of the audit committee (ACSIZE) is 5 persons approximately while the largest audit committee is constituted with 7 individuals and smallest committee are 3 persons only. The study reveals that, some audit committees are fully independent (ACIND) meaning none of the members are shareholder directors while opposite scenario is also true. But on average, almost $39 \%$ members of the audit committee are non-shareholding or independent directors. Data regarding, audit committee meetings (ACDILI) reveal that on average audit committee members meet 8.17 times. The numbers of meetings range between 26 to 4 times each year. The study finds that, the average total assets of the sampled firms is BDT 154,607.28 million, while the highest reported TA is BDT 899,599 million. It is noted that, the average ratio of profit to total assets is $1.1 \%$, meaning that the average profit of sample firms is $1.1 \%$ of total assets. The descriptive statistics also reveal that, the highest number of subsidiaries in the sampled companies is 7 and on average $35 \%$ of the 230 sampled annual reports are audited by Big 4 affiliated auditing firms. 


\section{IIMacrothink}

Table 6. Pearson Correlation Matrix

\begin{tabular}{|c|c|c|c|c|c|c|c|c|c|c|c|c|c|c|}
\hline & VIF & $\begin{array}{l}\text { Ln } \\
\text { AUDFEES }\end{array}$ & $\begin{array}{l}\text { BOD } \\
\text { SIZE }\end{array}$ & $\begin{array}{l}\text { BOD } \\
\text { IND }\end{array}$ & $\begin{array}{l}\text { BOD } \\
\text { DILI }\end{array}$ & $\begin{array}{l}\text { BOD } \\
\text { FFM }\end{array}$ & $\begin{array}{l}\text { AC } \\
\text { SIZE }\end{array}$ & $\begin{array}{l}\text { AC } \\
\text { IND }\end{array}$ & $\begin{array}{l}\text { AC } \\
\text { DILI }\end{array}$ & $\begin{array}{l}\text { Ln } \\
\text { PROFIT }\end{array}$ & PROFIT & $\operatorname{ComX}$ & LOSS & BIG4 \\
\hline Ln & & 1.000 & & & & & & & & & & & & \\
\hline \multicolumn{15}{|l|}{ AUD } \\
\hline \multicolumn{15}{|l|}{ FEE } \\
\hline BOD & 1.99 & $.276^{* * *}$ & 1.000 & & & & & & & & & & & \\
\hline \multicolumn{15}{|l|}{ SIZE } \\
\hline BOD & 1.91 & -.047 & $-.426 * * *$ & 1.000 & & & & & & & & & & \\
\hline \multicolumn{15}{|l|}{ IND } \\
\hline BOD & 2.34 & $.470 * * *$ & $.373 * * *$ & $-.197 * * *$ & 1.000 & & & & & & & & & \\
\hline \multicolumn{15}{|l|}{ DILI } \\
\hline BOD & 1.2 & .088 & $-.241 * * *$ & $.252 * * *$ & $-.141 * *$ & 1.000 & & & & & & & & \\
\hline \multicolumn{15}{|l|}{ FEM } \\
\hline $\mathbf{A C}$ & 1.8 & $-.183^{* * *}$ & $.227 * * *$ & $-.176^{* * *}$ & -0.005 & $-.169^{* *}$ & 1.000 & & & & & & & \\
\hline \multicolumn{15}{|l|}{ SIZE } \\
\hline AC & 2.34 & $.318 * * *$ & 0.067 & $.400 * * *$ & $.238 * * *$ & 0.051 & $507 * * *$ & 1.000 & & & & & & \\
\hline \multicolumn{15}{|l|}{ IND } \\
\hline $\mathrm{AC}$ & 2.15 & $.463 * * *$ & $.417^{* * *}$ & $-.155^{* *}$ & $.682 * * *$ & $-.163^{* *}$ & -0.005 & $.212 * *$ & 1.000 & & & & & \\
\hline \multicolumn{15}{|l|}{ DILI } \\
\hline Ln & 3.84 & $.765^{* * *}$ & $.437 * * *$ & $-.116^{*}$ & $.599 * * *$ & -0.076 & $.299 * * *$ & $.508^{* *}$ & $.546^{* *}$ & 1.000 & & & & \\
\hline \multicolumn{15}{|l|}{ FSIZE } \\
\hline PROFIT & 2.87 & $-.408 * * *$ & -0.132 & $.137 * *$ & -0.301 & -0.1 & 0.15 & -0.174 & -0.295 & -0.398 & 1.000 & & & \\
\hline $\operatorname{ComX}$ & 1.69 & $.669 * * *$ & $.279 * * *$ & -0.039 & $.301 * * *$ & 0.035 & -0.032 & $.271^{* *}$ & $.200 * *$ & $.584 * * *$ & -0.179 & 1.000 & & \\
\hline LOSS & 3.14 & -.047 & $-.203 * * *$ & $-.139 * *$ & $-.183^{* * *}$ & 0.041 & 0.042 & $-.213^{* *}$ & -0.106 & $-.261 * * *$ & $-.370 * * *$ & $.209 * * *$ & 1.000 & \\
\hline BIG4 & 1.13 & $.174 * * *$ & $-.115^{*}$ & 0.035 & -0.077 & $.220 * * *$ & -0.083 & 0.047 & -0.02 & 0.107 & -0.082 & 0.044 & 0.005 & 1.000 \\
\hline
\end{tabular}

Note: * indicates significance at $10 \%$ level; ** indicates significance at $5 \%$ level; *** indicates significance at $1 \%$ level.

\subsection{Correlation Analysis}

Table 6 shows the Pearson correlation matrix among explanatory variables. All of the experimental variables except BODIND and ACSIZE have positive associations with LnAUDFEE. In the case of control variables LnFSIZE, ComX and BIG4 have positive correlation with LnAUDFEE while the PROFIT and LOSS both show negative relation. The maximum pair-wise positive correlation exists between LnFSIZE and LnAUDFEE. While maximum pair-wise negative correlation exists between ACSIZE and ACIND. It indicates that there is no potential multicollinearity problem in the regression model as suggested by Hair et al. (2010). 


\subsection{Multivariate Regression Results}

The results of the regression analysis appear in Table 7. To clearly illustrate the effects of experimental variables the study runs two separate models. Model 1 regresses LnAUDFEE on only the five control variables derived from extant literature and finds that each of the control variables are statistically significant. As expected, audit fee is positively associated FSIZE, ComX, LOSS and BIG4 and negatively associated with PROFIT. The value of adjusted $\mathrm{R}^{2}$ is 0.696 which indicates that only control variables explain $69.6 \%$ of the variation in audit fees of Bangladeshi banks and non-bank financial institutions.

Table 7. Summery of Regression Output

\begin{tabular}{|c|c|c|c|c|c|}
\hline \multirow[b]{2}{*}{ Variable } & \multirow[b]{2}{*}{$\begin{array}{l}\text { Sign } \\
\text { Exp. }\end{array}$} & \multicolumn{4}{|c|}{ Dependent Variable $=$ LnAUDFEE } \\
\hline & & \multicolumn{2}{|c|}{ Model 1} & \multicolumn{2}{|l|}{ Model 2} \\
\hline $\mathrm{C}$ & $?$ & 2.719 & $0.000 * * *$ & 3.092 & $0.000 * * *$ \\
\hline BODSIZE & + & - & - & -0.005 & 0.248 \\
\hline BODIND & + & - & - & 1.192 & $0.000 * * *$ \\
\hline BODDILI & + & - & - & 0.002 & 0.581 \\
\hline BODFEM & + & - & - & 0.791 & $0.000 * * *$ \\
\hline ACSIZE & + & - & - & -0.051 & $0.036^{* *}$ \\
\hline ACIND & + & - & - & -0.919 & $0.000 * * *$ \\
\hline ACDILI & + & - & - & 0.033 & $0.000 * * *$ \\
\hline Ln FSIZE & + & 0.409 & $0.000 * * *$ & 0.394 & $0.000 * * *$ \\
\hline PROFIT & - & -5.389 & $0.001 * * *$ & -4.064 & $0.087^{*}$ \\
\hline ComX & + & 0.211 & $0.000 * * *$ & 0.224 & $0.000 * * *$ \\
\hline LOSS & + & 0.543 & $0.000 * * *$ & 0.569 & $0.000 * * *$ \\
\hline BIG4 & + & 0.188 & $0.000 * * *$ & 0.158 & $0.000 * * *$ \\
\hline $\mathrm{N}=$ & & 230 & & 230 & \\
\hline R-squared = & & 0.708 & & 0.745 & \\
\hline Adj. R-squared = & & 0.696 & & 0.726 & \\
\hline F-statistic $=$ & & 59.231 & & 38.98 & \\
\hline $\operatorname{Prob}(\mathrm{F}$-statistic $)=$ & & 0.000 & & 0.000 & \\
\hline Marginal Contribution (F rati & & 4.498 & & & \\
\hline Model 2 vs. Model 1)(note 4) & & (P-value $=$ & $* * *)$ & & \\
\hline Durbin-Watson statistic $=$ & & 0.486 & & 0.578 & \\
\hline
\end{tabular}

Note: * indicates significance at the $10 \%$ level; ** indicates significance at the $5 \%$ level; *** indicates significance at the $1 \%$ level.

On the other hand, Model 2 tests LnAUDFEE on seven experimental variables and the five control variables jointly. The study finds that, BODIND, BODFEM and ACDILI have significant positive influence on audit fees and the result is consistent with prior literature. Therefore, hypotheses $\mathrm{H}_{2}, \mathrm{H}_{4}$ and $\mathrm{H}_{7}$ are supported.

$\mathrm{H}_{2}$ predicts that board independence has a positive relationship with audit fees, and it is supported by the result consistent with prior literature (e.g. Jizi \& Nehme, 2018; Bozec \& Dia, 
2017; Kumar, 2014; Kikhia, 2014; Carcello et al., 2002).

Result relating to $\mathrm{H}_{4}$ suggests that a positive association exists between female member representation in board and audit fees. The result of this study is consistent with prior literature (e.g. Lai et al., 2017 ; Khlif \& Achek, 2017; Hardies et al., 2015; Huang et al., 2014).

$\mathrm{H}_{7}$ predicts audit committee diligence has a positive influence on audit fees and the result is also consistent with prior literature (e.g. Jizi \& Nehme, 2018; Yatim et al., 2006; Stewart \& Kent 2006; Abbott et. al., 2003)

It should be noted that, the coefficients of both ACSIZE and ACIND are statistically significant but shows negative associations with LnAUDFEE which is inconsistent with prior literature. However, BODDILI shows a positive association, with no statistical significance and another important variable, BODSIZE, found to have negative associations with LnAUDFEE and it is also statistically insignificant. The value of adjusted $\mathrm{R}^{2}$ of Model 2 is 0.726 suggesting that $72.6 \%$ of the variation in audit fees is explained by the experimental and control variables.

The study compares the value of $\mathrm{R}^{2}$ of the two models and finds that the incremental F-statistic associated with testing Model 2 against the Model 1 is significant at $\mathrm{p}<0.01$.

\section{Sensitivity Test}

Considering the possible difference between the sampled companies in terms of their managerial philosophy, competence and other firm specific factors. The study tested one-way fixed group effect model (LSDV) by including dummy variable for each 46 companies. The result showed that the overall model fit increased significantly but almost all of the variables lost statistical significance because of having high multicollinearity issues in newly added dummy variables. Additionally, in this short panel having 46 cross-sections (entity) covering only five years data, one-way fixed group effect model includes a large number of dummy variables and creates incidental parameter problem therefore returns less efficient estimators.

To address the potential industry effect on audit fees the study introduced additional two dummy variables for banks (1) and NBFIs (0). The result of the regression confirmed that the results for experimental variables remained qualitatively unchanged.

In the presence of heteroskedasticity and significant outliers, the study employs White's heteroskedasticity-corrected standard errors also known as robust standard errors.

In Table 6 the results of variance inflation factor (VIF) tests for multicollinearity have been presented. As suggested by Greene (2008), when VIF is greater than 10, it is considered as the existence of high multicollinearity. The highest VIF among all the variables tested is 3.84 (LnFSIZE) and the lowest is 1.13 (BIG4). It suggests that multicollinearity problems are unlikely in the regression models of the study.

The study used natural log of audit fee to test the variables. For sensitivity analysis, audit fee 
is defined as deflated by assets (Simunic, 1980). In line with the methodology of Simunic (1980), LnAUDFEE is regressed on FSIZE and the resulting coefficient associated with FSIZE, 0.56, is used to scale total assets in computing a new dependent variable DFAUDFEE. Then DFAUDFEE is computed as Audit Fees/Total Assets ${ }^{0.56}$. Finally, LnAUDFEE has been replaced by DFAUDFEE to run the Model 2 again (removing FSIZE from the equation). The (unreported) results confirmed the value of adjusted $\mathrm{R}^{2}$ decreased to $71.6 \%$ along with $\mathrm{DW}$ statistics to 0.36 however, among experimental variables BODSIZE shows significant positive influence but BODIND lost its statistical significance. It is interesting to note that, ACIND's significant negative association with LnAUDFEE changed in significant positive association with DFAUDFEE. Exactly, opposite scenario takes place in relation to BODFEM.

Bangladesh Securities and Exchange Commission (BSEC) issued the first draft Code of Corporate Governance (See Note: 2) during late 2012 and all the sampled listed companies started to comply with them from 2013. The study tests data starting from 2013 to 2017 which confirms that the study has no chance for structural break leading to unreliability of the models.

\section{Conclusion}

The study examines 230 observations from Bangladeshi listed banks and non-bank financial institutions (NBFIs) in order to find out the relationship between various corporate governance variables and audit fees in Bangladesh. The study tests a total of twelve different variables of which seven belong to corporate governance and the rest of the variables are included as control variables. From Bangladesh perspective, a good number of research activities have been conducted on corporate governance issues, however, very few prior studies examine the link between corporate governance mechanisms and audit fees. This study extends the literature by testing the impact of each corporate governance variable separately as opposed to the methodology used by Haque et al. (2019) by examining composite score of CG variables only.

The variables have been studied in two different models. In Model 1, only firm-specific controlled variables, namely firm size, profitability, loss, number of subsidiaries and the affiliation of firm's external auditor with Big 4 have been examined. Results show that all the control variables are statistically significant and each of them depicts the similar association with audit fees as supported by prior literature. The value of adjusted $\mathrm{R}^{2}$ shows of the model confirms that $69.6 \%$ of the variation in audit fees is measured by the control variables of this study.

Finally, the Model 2 includes all of the twelve variables and regress to find out the possible impact of corporate governance variables on audit fees. Among the variables tested, board independence, female member representation at board and audit committee diligence has a significant positive influence on audit fees thus the results confirm the prior literature. Board diligence also has a positive impact on the dependent variable, but the result is not 
statistically significant. However, rest of the corporate governance variables, namely board size, audit committee size, audit committee independence has negative associations with audit fees which is contrary to the expectation of the study and previous literature as well. The overall model fit measured as by adjusted $\mathrm{R}^{2}$ shows $72.6 \%$ of the variation in audit fees is measured by the corporate governance variables along with control variables of this study. In addition to that, the study measures the incremental/marginal contribution of the Model 2 over Model 1 and concludes its significance at $p<0.01$.

The paper is subject to several limitations. Firstly, the sample is limited to banks and NBFIs only as a result it is difficult to confirm the extent to which this result applies in other settings. Secondly, the study ignores the potential endogeneity issues between audit fee and the variables of corporate governance. Finally, the study covers only the period, which after introducing comprehensive corporate governance codes by BSEC which leaves the scope for studying audit fees by comparing data before the code was introduced.

The result of this research adds to the growing body of literature that finds a connection between corporate governance and various facets of the financial reporting and audit processes around the world.

\section{Notes:}

1. Bangladesh Securities and Exchange Commission. 2018. Corporate Governance Code. (No.BSEC/CMRRCD/2006-158/207/Admin/80). Available at: www.sec.gov.bd/slaws/Corporate_Governance_Code_10.06.2018.pdf; Accessed: 25 June, 2019

2. Bangladesh Securities and Exchange Commission. 2018. Draft Corporate Governance Code. (No. BSEC/CMRRCD/2006-158/134/Admin/44), Available at:

https://www.dsebd.org/pdf/Notification_on_20CG-070812-Amended.pdf; Accessed: 25 June, 2019

\section{References}

Abbott, L. J., Parker, S., Peters, G. F., \& Raghunandan, K. (2003). The association between audit committee characteristics and audit fees. A Journal of Practice \& Theory, 22(2), 17-32. https://doi.org/10.2308/aud.2003.22.2.17

Abbott, L. J., \& Parker, S. (2000). Auditor selection and audit committee characteristics. A Journal of Practice and Theory, 19(2), 47-66. https://doi.org/10.2308/aud.2000.19.2.47

Adams, R., \& Ferreira, D. 2009. Women in the boardroom and their impact on governance and performance. Journal of Financial Economics, 94(2), 291-309. https://doi.org/10.1016/j.jfineco.2008.10.007

Ahmed, H. L., Alam, M. J., Jafar, S. A., \& Zaman, S. H. (2008). A conceptual review on 
corporate governance and its effect on firm's performance: Bangladesh perspective. AIUB Business and Economics Working Paper Series, No 2008-10. Retrieved 18 May, 2019 from http://orp.aiub.edu/WorkingPaper/WorkingPaper.aspx?year=2008

Alam, M. R., \& Akhter, F. (2017). Impact of corporate governance on performance of commercial banks in Bangladesh. The Cost and Management, 45(4), 02-09.

Al-Baidhani, A. M. (2016). The role of audit committee in corporate governance: Descriptive study. International Journal of Research \& Methodology in Social Science, 2(2), 45-57.

Ali, M. J., Singh, R. K. S., \& Al-Akra, M. (2018). The impact of audit committee effectiveness on audit fees and non-audit service fees: Evidence from Australia. Accounting Research Journal, 31(2), 174-191. https://doi.org/10.1108/ARJ-11-20150144

Altunbas, Y., Gardener, E. P. M., Molyneux, P., \& Moore, B. (2001). Efficiency in European banking. European Economic Review, 45(10), 1931-1955. https://doi.org/10.1016/S0014-2921(00)00091-X

Azmi, N.A., Samat, O., Zakaria, N. B., \& Yusof, M. A. M. (2013). Audit committee attributes on audit fees. The impact of Malaysian code of corporate governance (MCCG) 2007. Journal of Modern Accounting and Auditing, 9(11), 1442-1453.

Beasley, M. S., Carcello, J. V., Hermanson, D. R., \& Lapides, P. D. (2000). Fraudulent financial reporting consideration of industry traits and corporate governance mechanisms. Accounting Horizons, 14(4), 14-21. https://doi.org/10.2308/acch.2000.14.4.441

Beasley, M. (1996). An empirical analysis of the correlation between the board of direction composition and financial statements fraud. The Accounting Review, 71(4), 443-465.

Bedard, J. C., \& Johnstone, K. M. (2010). Audit partner tenure and audit planning and pricing. A Journal of Practice and Theory, 29, 45-70. https://doi.org/10.2308/aud.2010.29.2.45

Beiner, S., Drobetz, W., Schmid, F., \& Zimmermann, H. (2004). Is board size an independent corporate governance mechanism? Kyklos, 57(3), 327-356. https://doi.org/10.1111/j.0023-5962.2004.00257.x

Belal, A., Spence, C., Carter, C., \& Zhu, J. (2017). The Big 4 in Bangladesh: Caught between the global and the local. Accounting, Auditing \& Accountability Journal, 30(1), 145-163. https://doi.org/10.1108/AAAJ-10-2014-1840

Belkhir, M. (2006). Board structure, ownership structure, and firm performance: Evidence from banking. Applied Financial Economics, 19(19), 1581-1593.

Bernardi, R. A., \& Arnold, D. F. (1997). An examination of moral development within public accounting by gender, staff level, and firm. Contemporary Accounting Research, 14, 653-668. https://doi.org/10.1111/j.1911-3846.1997.tb00545.x

Biswas, P. K. (2015). Corporate governance and its determinants in emerging countries: A case study of Bangladesh. International Journal of Disclosure and Governance, 12(1), $1-28$. 
Bortolon, P. M., Neto, A. S., \& Santos, T. B. (2013). Audit costs and corporate governance. $\begin{array}{lllll}\text { Revista Contabilidade } \quad \& \quad \text { Finanças, } & 24 \quad \text { (61), }\end{array}$ http://dx.doi.org/10.1590/S1519-70772013000100004.

Bozec, R., \& Dia, M. (2017). Monitoring function of the board and audit fees: Contingent upon ownership concentration. International Journal of Accounting \& Information Management, 25(1), 70-90. https://doi.org/10.1108/IJAIM-05-2016-0054

Brinn, T., Peel, M. J., \& Roberts, R. (1994). Audit fee determinants of independent and subsidiary unquoted companies in the UK - An exploratory study. British Accounting Review, 26(2), 101-121. https://doi.org/10.1006/bare.1994.1009

Carcello, J. V., Hermanson, D. R., Neal, T. L., \& Riley, R. A. (2002). Board characteristics and audit fees. Contemporary Accounting Research, 19(3), 365-384. https://doi.org/10.1506/CHWK-GMQ0-MLKE-K03V

Carcello, J. V., \& Neal, T. L. (2000). Audit committee composition and auditor reporting. The Accounting Review, 75(4), 453-467. https://doi.org/10.2308/accr.2000.75.4.453

Carter, D., Simkins, B., \& Simpson, W. (2003). Corporate governance, board diversity, and firm value. The Financial Review, 38, 33-53. https://doi.org/10.1111/15406288.00034

Chan, P., Ezzamel, M., \& Gwilliam, D. (1996). Determinants of audit fees for quoted UK companies. Journal of Business Finance and Accounting, 20(6), 765-786. https://doi.org/10.1111/j.1468-5957.1993.tb00292.x

Chartered Institute of Management Accountants. (2000). Corporate governance - history, practice and future. CIMA, London.

Cheffins, B. R. (2013). The history of corporate governance. In M. Wright, D. S. Siegel, K. Keasey and I. Filatotchev (Eds.). The Oxford Handbook of Corporate Governance, 46-64. Oxford: Oxford University Press.

Collier, P., \& Gregory, A. (1996). Audit committee effectiveness and the audit fee. European Accounting Review, 5, 177-198. https://doi.org/10.1080/09638189600000012

Crişan, A. R., \& Fülöp, M. T., (2014). The role of the audit committee in corporate governance-Case study for a sample of companies listed on BSE and the London stock exchange-FTSE 100. Procedia Economics and Finance, 15, 1033-1041.

Denis, D. K., \& McConnell, J. J. (2003). International corporate governance. Journal of Financial and Quantitative Analysis, 38(1), 1-36. https://doi.org/10.2307/4126762

DeZoort, T., Hermanson, D. R., Archambeault, D., \& Reed, S. (2002). Audit committee effectiveness: a synthesis of the empirical audit committee literature. Journal of Accounting Literature, 21, 38-75.

DeZoort, F. T., \& Salterio, S. E. (2001). The effects of corporate governance experience and financial-reporting and audit knowledge on audit committee members' judgments. $A$ Journal of Practice \& Theory, 20(2), 31-47. https://doi.org/10.2308/aud.2001.20.2.31 
Erhardt, N., Werbel, J., \& Shrader, C. (2003). Board of director diversity and firm financial performance. Corporate Governance: An International Review, 11(2), 102-110. https://doi.org/10.1111/1467-8683.00011

Fakhari, H., \& Pitenoei, Y. R. (2017). The impact of audit committee and its characteristics on the firms' information environment. Iranian Journal of Management Studies (IJMS), 10(3), 577-608. https://doi.org/10.22059/ijms.2017.231317.672627

Farooq, M. U., Kazim, I., Usman, M., \& Latif, M. I. (2018). Corporate governance and audit fees: Evidence from a developing country. Pakistan Journal of Commerce and Social Sciences, 12(1), 94-110.

Financial Reporting Council. (2012). The UK corporate governance code. Retrieved 18 May, 2019 from https://www.frc.org.uk/getattachment/e322c20a-1181-4ac8a3d31fcfbcea7914/UK

Gibson, M. M. (2003). Is corporate governance ineffective in emerging markets? Journal of Financial and Quantitative Analysis, 38(1), 231-250. https://doi.org/10.2307/4126771

Gonthier-Besacier, N., \& Schatt, A. (2007). Determinants of audit fees for French quoted firms. Managerial Auditing Journal, 22(2), 139-160. https://doi.org/10.1108/02686900710718654

Greco, G. (2011). Determinants of board and audit committee meeting frequency: Evidence from Italian companies. Managerial Auditing Journal, 26(3), 208-229. https://doi.org/10.1108/02686901111113172

Greene, W. (2008). Econometric analysis. New Jersey: Upper Saddle River. Pearson.

Gujarati, D. N., Porter, D. C., \& Gunasekar, S. (2014). Basic econometrics. New Delhi: Tata McGraw Hill Education Pvt Ltd

Hair, J. F., Black, W. C., Babin, B. J., \& Anderson, R. E. (2010). Multivariate data analysis: A global perspective, New Jersey: Upper Saddle River. Pearson.

Hamza, M. (2018). The impact of corporate governance on auditor's independence and audit fees: An empirical study of Jordanian insurance companies listed on Amman stock exchange. International Journal of Economics and Finance, 10(4), 171-178. https://doi.org/10.5539/ijef.v10n4p171

Haque T., Afroze, S. \& Fatema, T. Z. (2019). Impact of corporate governance on audit fees and audit quality: A study in the insurance industry of Bangladesh. The Cost and Management, 47(2), 4-11.

Haq, A., \& Leghari, M. K. (2015). Determinants of audit fee in Pakistan. Research Journal of Finance and Accounting, 6(9), 176-188.

Hardies, K., Breesch, D., \& Branson, J. (2015). The Female Audit Fee Premium. A Journal of Practice \& Theory, 34(4), 171-195. https://doi.org/10.2308/ajpt-51079 
Harris, C. K. (2007). The association between corporate governance and audit fees. Business and Economics Faculty Publications. Retrieved 15 June, 2019 from https://digitalcommons.ursinus.edu/bus_econ_fac/32

Hassan, M., Hassan, S., Iqbal, A. \& Khan, M. F. A. (2014). Impact of corporate governance on audit fee: Empirical evidence from Pakistan. World Applied Sciences Journal, 30(5), 645-651. https://doi.org/10.5829/idosi.wasj.2014.30.05.14093

Hassan, Y. M., \& Naser, K. (2013). Determinants of audit fees: Evidence from an emerging economy. International Business Research, 6(8), 13-25. https://doi.org/10.5539/ibr.v6n8p13

Hermalin, B. E. (2005). Trends in corporate governance. The Journal of Finance, 60(5), 2351-2384. https://doi.org/10.1111/j.1540-6261.2005.00801.x

Hossain, M. I., \& Rahman, M. J. (2013). Corporate governance practices in Bangladesh. Journal of Socio Economic Research and Development, 10(3), 1507-1511.

Huang, T. C., Huang, H. W., \& Lee, C. C. (2014). Corporate executive's gender and audit fees. Managerial Auditing Journal, 29(6), 527-547. https://doi.org/10.1108/MAJ-032013-0837

Huq, B. I. A., \& Bhuiya, M. Z. H. (2012). Corporate governance-its problems \& prospects in banking industry in Bangladesh. World Review of Business Research, 2(2), 16-31.

Husnin, A. I., Nawawi, A., \& Salin, A. S. A. P. (2013). Corporate governance structure and its relationship with audit fee-evidence from Malaysian public listed companies. Asian Social Science, 9(15), 305-317. https://doi.org/10.5539/ass.v9n15p305

Ittonen, K, \& Peni, E. (2012). Auditor's gender and audit fees. International Journal of Auditing, 16(1), 1-18.

Jensen, M. C. (1993). The modern industrial revolution, exit, and the failure of internal control systems. Journal of Finance, 48(3), 831-880. https://doi.org/10.1111/j.15406261.1993.tb04022.x

Jizi, M., \& Nehme, R. (2018). Board monitoring and audit fees: The moderating role of CEO/chair dual roles. Managerial Auditing Journal, 33(2), 217-243. https://doi.org/10.1108/MAJ-10-2016-1464

Kalbers, L. P., \& Fogarty, T. J. 1993. Audit committee effectiveness: An empirical investigation of the contribution of power. A Journal of Practice \& Theory, 12(1), 24-49.

Karim, K., Robin, A., \& Suh, S. (2015). Board structure and audit committee monitoring effects of audit committee monitoring incentives and board entrenchment on audit fees. Journal of Accounting, Auditing \& Finance, 31(2), 248-276. https://doi.org/10.1177/0148558X15583412

Karim, A. K. M. W., \& Hasan, T. (2012). The market for audit services in Bangladesh. Journal of Accounting in Emerging Economies, 2(1), 50-66. 
https://doi.org/10.1108/20421161211196120

Karim, A. K. M. W., \& Moizer, P. (1996). Determinants of audit fees in Bangladesh. The International Journal of Accounting, 31(4), 497-509. https://doi.org/10.1016/S0020-7063(96)90034-5

Khan, M., \& Habib, U. Z. (2010). The effect of corporate governance elements on corporate social responsibility (CSR) reporting: Empirical evidence from private commercial banks of Bangladesh. International Journal of Law and Management, 52(2), 82-109. https://doi.org/10.1108/17542431011029406

Khlif, H., \& Achek, I. (2017). Gender in accounting research: A review. Managerial Auditing Journal, 32(6), 627-655. https://doi.org/10.1108/MAJ-02-2016-1319

Kikhia, H. Y. (2015). Determinants of audit fees: Evidence from Jordan. Accounting and Finance Research, 4(1), 42-53. https://doi.org/10.5430/afr.v4n1p42

Kikhia, H. Y. (2014). Board characteristics, audit committee characteristics, and audit fees: Evidence from Jordan. International Business Research, 7(12), 98-110. https://doi.org/10.5539/ibr.v7n12p98

King, R. G., \& Levine, R. (1993a). Finance and growth: Schumpeter might be right. Quarterly Journal of Economics, 108(3), 717-737. https://doi.org/10.2307/211840

King, R. G., \& Levine, R. (1993b). Finance, entrepreneurship and growth: Theory and evidence. Journal of Monetary Economics, 32(3), 513-542. https://doi.org/10.1016/0304-3932(93)90028-E

Klien, A. (2002). Audit committee, board of director characteristics, and earnings management. Journal of Accounting and Economics, 33(3), 375-400. https://doi.org/10.1016/S0165-4101(02)00059-9

Lai, K. M. Y., Srinidhi, B., Gul, F. A., \& Tsui, J. S. L. (2017). Board gender diversity, auditor fees, and auditor choice. Contemporary Accounting Research, 34(3), 1681-1714. https://doi.org/10.1111/1911-3846.12313

Langendijk, H. (1997). The market for audit services in the Netherlands. The European Accounting Review, 6(2), 253-264. https://doi.org/10.1080/713764721

Levine, R. (2004). Finance and growth: Theory and evidence. Working Paper No. 10766. The National Bureau of Economic Research, Cambridge, USA.

Levine, R. (1997). Financial development and economic growth: Views and agenda. Journal of Economic Literature, 35(2), 688-726.

Lipton, M., \& Lorsch, J. (1992). A modest proposal for improved corporate governance. The Business Lawyer, 48(1), 59-77.

Liu, S. (2017). An empirical study: Auditors' characteristics and audit fee. Open Journal of Accounting, 6(2), 52-70. https://doi.org/10.4236/ojacct.2017.62005 
Mahmud, S., \& Ara, J. (2015). Corporate governance practices in Bangladesh: An overview of its present scenario in banking industry. International Journal of Economics, Commerce and Management, 3(12), 408-425

Mellett, H., Peel, M. J., \& Karbhari, Y. (2007). Audit fee determinants in the UK university sector. Financial Accountability and Management, 23(2), 155-188. https://doi.org/10.1111/j.1468-0408.2007.00424.x

Mendez, C. F., \& García, R. A. (2007). The effects of ownership structure and board composition on the audit committee meeting frequency: Spanish evidence. Corporate Governance: An International Review, 15(5), 909-922. https://doi.org/10.1111/j.1467-8683.2007.00619.x

Moizer, P. (1997). Auditor reputation: The international empirical evidence. International Journal of Auditing, 1(1), 61-74. https://doi.org/10.1111/10991123.00013

Naser, K., \& Nuseibeh, R. (2008). Determinants of audit fees: Empirical evidence from an emerging economy. International Journal of Commerce and Management, 17(3), 239-254. https://doi.org/10.1108/10569210710833635

Paltrow, S. J. (2002). Accounting for the fall: accounting scandals have some peering at industry's self-policing. The Wall Street Journal. Retrieved 18 May, 2019 from www.wsj.com/articles/SB1010963336547708960

Raghunandan, K., \& Rama, D. V. (2007). Determinants of audit committee diligence. Accounting Horizons, 21(3), 265-279. https://doi.org/10.2308/acch.2007.21.3.265

Rahim, M. F. A., Johari, R. J., \& Takril, N. F. (2015). Revisited note on corporate governance and quality of audit committee: Malaysian perspective. Procedia Economics and Finance, 28, 213-221. https://doi.org/10.1016/S22125671(15)01102-8

Rubin, M. A. (1988). Municipal audit fee determinants. The Accounting Review, 63(2), 219-236.

Safiuddin, M., \& Mohsin, M. (2016). Determinants of audit fees: An empirical study on listed Bangladeshi companies. Independent Business Review, 9(1), 116-131.

Saha, M., \& Ghosh, T. (2019). Does corporate governance has impact on non-performing loan: A study on Bangladesh banking sector. The Cost and Management, 47(1), 48-56.

Sattar, S. (2018). Independent directors and good corporate governance. The Daily Star, June 12, 2018. Retrieved 12 June, 2019 from https://www.thedailystar.net/law-our-rights/law vision/independent-directors-and-good-corporate-governance-1589872

Shamsuddoha, M. (2003). Corporate governance practices in Bangladesh: The new paradigm in management education, Corporate Governance and Corporate Citizenship: Challenges for Business and Management Education, Bhubaneswar, Orissa, India, August, 26-27.

Sharma, V., Naicker, V., \& Lee, B. (2009). Determinants of audit committee meeting frequency: Evidence from a voluntary governance system. Accounting Horizons, 23(3), 
245-263. https://doi.org/10.2308/acch.2009.23.3.245

Shleifer, A., \& Vishny, R. W. (1997). A survey of corporate governance. The Journal of Finance, 52(2), 737-783. https://doi.org/10.1111/j.1540-6261.1997.tb04820.x

Simpson, W. G., \& Gleason, A. E. (1999). Board structure, ownership, and financial distress in banking firms. International Review of Economics and Finance, 8(3), 281-292. https://doi.org/10.1016/s1059-0560(99)00026-x

Simunic, D. A. (1984). Auditing, consulting, and auditor independence. Journal of Accounting Research, 22(2), 679-702.

Simunic, D. A. (1980). The pricing of audit services: Theory and evidence. Journal of Accounting Research, 18, 161-190. https://doi.org/10.2307/2490397

Smith Committee. (2003). Audit committees - Combined code guidance. Report for Financial Reporting Council. January, Holborn Hall, London. Retrieved 23 May, 2019 from www.ecgi.org/codes/documents/ac_report.pdf

Sonnenfeld, J. A. (2002). What makes great boards great? Harvard Business Review. Retrieved 5 June, 2019 from https://hbr.org/2002/09/what-makes-great-boards-great

Stewart, J. D., \& Kent, P. (2006). The relation between external audit fees, audit committee characteristics and internal audit. Accounting and Finance, 46(3), 387-404. https://doi.org/10.1111/j.1467-629X.2006.00174.X

Taylor, M. H., \& Simon, D. T. (1999). Determinants of Audit fees: the importance of litigation, disclosure and regulatory burdens in audit engagements in 20 countries. The International Journal of Accounting, 34(3), 375-388. https://doi.org/10.1016/S0020-7063(99)00017-5 Get

Urhoghide, R. O., \& Izedonmi, F. O. I. (2015). An empirical investigation of audit fee determinants in Nigeria. International Journal of Business and Social Research, 5(8), 48-58.

Vafeas, N. (1999). Board meeting frequency and firm performance. Journal of Financial Economics, 53(1), 113-142. https://doi.org/10.1016/S0304-405X(99)00018-5

Vera-Munoz, S. C. (2005). Corporate governance reforms: Redefined expectations of audit committee responsibilities and effectiveness. Journal of Business Ethics, 62(2), 115-127. https://doi.org/10.1007/s10551-005-0177-5

Wise, V., Ali, M. M., \& Yadav, S. K. S. (2014). Problems and prospects for corporate governance in Bangladesh: Some case studies basis analysis. Journal of International Trade and Commerce, 3(1), 31-54.

Willekens, M., Bauwhede, H. V., \& Gaeremynck, A. (2004). Voluntary audit committee formation and practices among Belgian listed companies. International Journal of Auditing, 8(3), 207-222. https://doi.org/10.1111/j.1099-1123.2004.00091.x 
Wu, Xingze. (2012). Corporate governance and audit fees: Evidence from companies listed on the Shanghai stock exchange. China Journal of Accounting Research, 5(4), 321-342. https://doi.org/10.1016/j.cjar.2012.10.001

Yatim, P., Kent, P., \& Clarkson, P. (2006). Governance structures, ethnicity, and audit fees of Malaysian listed firms. Managerial Auditing Journal, 21(7), 757-782. https://doi.org/10.1108/02686900610680530

Yin, F., Gao, S., Li, W., \& Lv, H. (2012). Determinants of audit committee meeting frequency: evidence from Chinese listed companies. Managerial Auditing Journal, 27(4), 425-444. https://doi.org/10.1108/02686901211218003

\section{Notes}

Note 1. Audit Committee Role and Practices. Available at: https://www.cfainstitute.org/en/advocacy/issues/audit-committee-role-practices

Note 2. The remaining 7 non-bank financial institution's annual report has incomplete or inconsistent data as well as data from entities to which BSEC has granted exemption of CG codes.

Note 3. Nurul Faruk Hasan \& Co. has become the part of Deloitte on 31 December, 2018. But the effect of this affiliation has no impact on this study because it only considers data up to year 2017. (Available at: https://www2.deloitte.com/bd/en/pages/about-deloitte/articles/deloitte-enters-bangladesh.htm 1)

Note 4. Gujarati et al., (2014):

$$
\frac{\left(R_{\text {Model } 2}^{2}-R_{\text {Model } 1}^{2}\right)}{\text { Number of new regressors }} \div \frac{\left(1-R_{\text {Model } 2}^{2}\right)}{\left(n-\text { number of parameters in } \text { Model }_{2}\right)}
$$

\section{Copyright Disclaimer}

Copyright for this article is retained by the author(s), with first publication rights granted to the journal.

This is an open-access article distributed under the terms and conditions of the Creative Commons Attribution license (http://creativecommons.org/licenses/by/3.0/). 